\title{
A Systematic Review of e-Service Learning in Higher Education
}

\author{
https://doi.org/10.3991/ijim.v14i06.13395
}

\author{
Valerie Bukas Marcus $\left({ }^{凶}\right)$, Noor Azean Atan, Sanitah Mohd Yusof, Lokman Tahir \\ Universiti Teknologi Malaysia, Johor, Malaysia. \\ valeriebukas92@gmail.com
}

\begin{abstract}
E-Service Learning is a service-learning course when the instruction and/or the service occurs online gains popularity among educators as we are transitioning to online learning platforms. The current study presents a systematic review of papers on the research involved information and communications technology (ICT) in the service-learning project. Studies have noted the growing use of ICT in service-learning projects for various purposes such as for communication and collaboration, data collection, reflection, and instruction delivery. However, very little research analysed students' engagement in this eService Learning environment. Future research should be done to investigate an effective application of technology in service-learning courses, especially to attain the attention of digital natives nowadays and engaging learners instead of merely using technologies in service-learning courses.
\end{abstract}

Keywords-E-Service-Learning; Online Service Learning; Technology Integration

\section{$1 \quad$ Introduction}

Educational paradigm that shifts toward distance and technology-supported course delivery birthed e-Service Learning [1]. Originally, e-Service Learning existed when instructors feels that student is disengage in online learning platform. Thus, combining it with Service Learning pedagogy will be able to cater to this gap since the nature of Service Learning required students to interact with each other, and throughout the learning process. With such a promising educational setting, e-Service Learning has gained a lot of attention among Service Learning practitioners. While there is an abundance of literature on service learning, as there is on e-learning, the area of eservice learning is still under-researched. Therefore, this article aims to study the area of research that has been explored in e-Service Learning so far. This study is vital as to date there is no systematic review presenting research trend in e-Service Learning despite the overwhelming claims stating that e-Service Learning bring benefits as much as traditional Service Learning. Major contribution of this article is to help fellow researchers that is interested in studying e-Service Learning regarding what current research has been done in e-Service Learning field, thus providing more insights, keep themselves up to date with this field and suggesting future directions of e- 
Service Learning. To develop a relevant systematic review, the literature study was geared by the main research question- what has been studied in e-Service Learning? This study places its focus on the objective of e-Service Learning research that has been explored. A special focus was given to research of e-Service Learning in Higher Education setting because in this tertiary level, students will be equipped with skills that we aspired to produce - a future proof talents.

\section{$2 \quad$ Methodology}

The systematic review was conducted in line with the Preferred Reporting Items for Systematic Reviews and Meta-Analyses (PRISMA; see Figure 1). PRISMA is often referred to within the information science field. The PRISMA statement allows for rigorous search of terms related to research that has been done in e-Service Learning.

\subsection{Resources}

Electronic databases such as Web of Science (WoS) and Scopus were used to conduct literature searches with a related relevant keyword to identify articles (see Figure 1). WoS is a robust database covering more than 250 field of studies and consisting more than 30000 journals meanwhile Scopus is one of the largest abstracts and citation databases of peer-reviewed literature and it provide extensive journal in social sciences such as education field.

\subsection{Identification}

The first phase identified keywords used for the search process. Relying on previous studies and thesaurus, keywords similar and related to e-Service Learning was used.

Table 1. The Search String

\begin{tabular}{|c|c|}
\hline Databases & Keywords Used \\
\hline Scopus & $\begin{array}{l}\text { TITLE-ABS-KEY ( ( }\{\text { e-service learning }\} \text { OR }\{\text { service e-learning }\} \text { OR }\{\text { e-service- } \\
\text { learning }\} \text { OR }\{\text { service learning online }\} \text { OR \{online service learning }\} \text { OR }\{\text { online } \\
\text { service-learning }\} \text { OR }\{\text { service-learning online }\})) \text { AND }((\{\text { service learning }\} \text { AND } \\
\text { \{technology integration }\}) \text { OR (\{service learning }\} \text { AND }\{\text { ict }\}))\end{array}$ \\
\hline Web of Science & 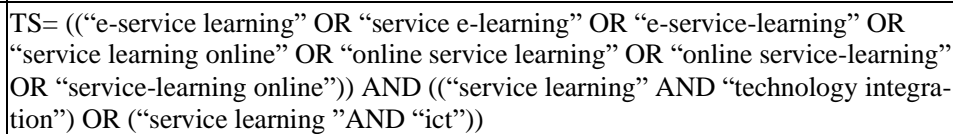 \\
\hline
\end{tabular}

\subsection{Screening}

Several inclusion and exclusion criterion are determined. First, in relation to literature type, article journals, book chapters and Scopus-indexed conference proceeding 
are selected. Only articles in English are selected for review to avoid any confusion and difficulty in translating. Authors also only include article that is based on Higher Education setting. Selected article also must portray that they integrate technology during Service Learning phase. Then, each study was assessed against a set of inclusion and exclusion criteria. Excluded studies were tabulated against reasons for exclusion.

Table 2. Inclusion and Exclusion Criteria

\begin{tabular}{|l|l|l|}
\hline \multicolumn{1}{|c|}{ Criterion } & \multicolumn{1}{|c|}{ Eligibility } & \multicolumn{1}{c|}{ Exclusion } \\
\hline Literature Type & $\begin{array}{l}\text { Journal (research articles), book chapter, } \\
\text { Scopus-indexed conference proceeding }\end{array}$ & $\begin{array}{l}\text { Journals (systematic review, review, meta - } \\
\text { analysis, meta-synthesis) }\end{array}$ \\
\hline Language & English & Non English \\
\hline Setting & Higher Education & High schools, primary schools, kindergarten \\
\hline Subject Area & $\begin{array}{l}\text { Integrate technology during Service Learn- } \\
\text { ing phase }\end{array}$ & $\begin{array}{l}\text { Did not integrate technology during Service } \\
\text { Learning }\end{array}$ \\
\hline
\end{tabular}

\subsection{Eligibility}

The remaining articles resulted from screening process then are gone through the third process - eligibility. In this stage, authors manually examined all the articles thoroughly to ensure it fit the criteria determined. A full-text review was conducted for eligible studies, with the finalized set of published studies subjected to qualitative synthesis. Analysis was focused on specific studies that related to formulated questions. The data were extracted by reading through the abstract first then the full articles (in-depth) to identify appropriate themes and subthemes. Qualitative analysis was performed using thematic analysis in Nvivo 12 to identify themes related to research area that has been studied in e-Service Learning. 

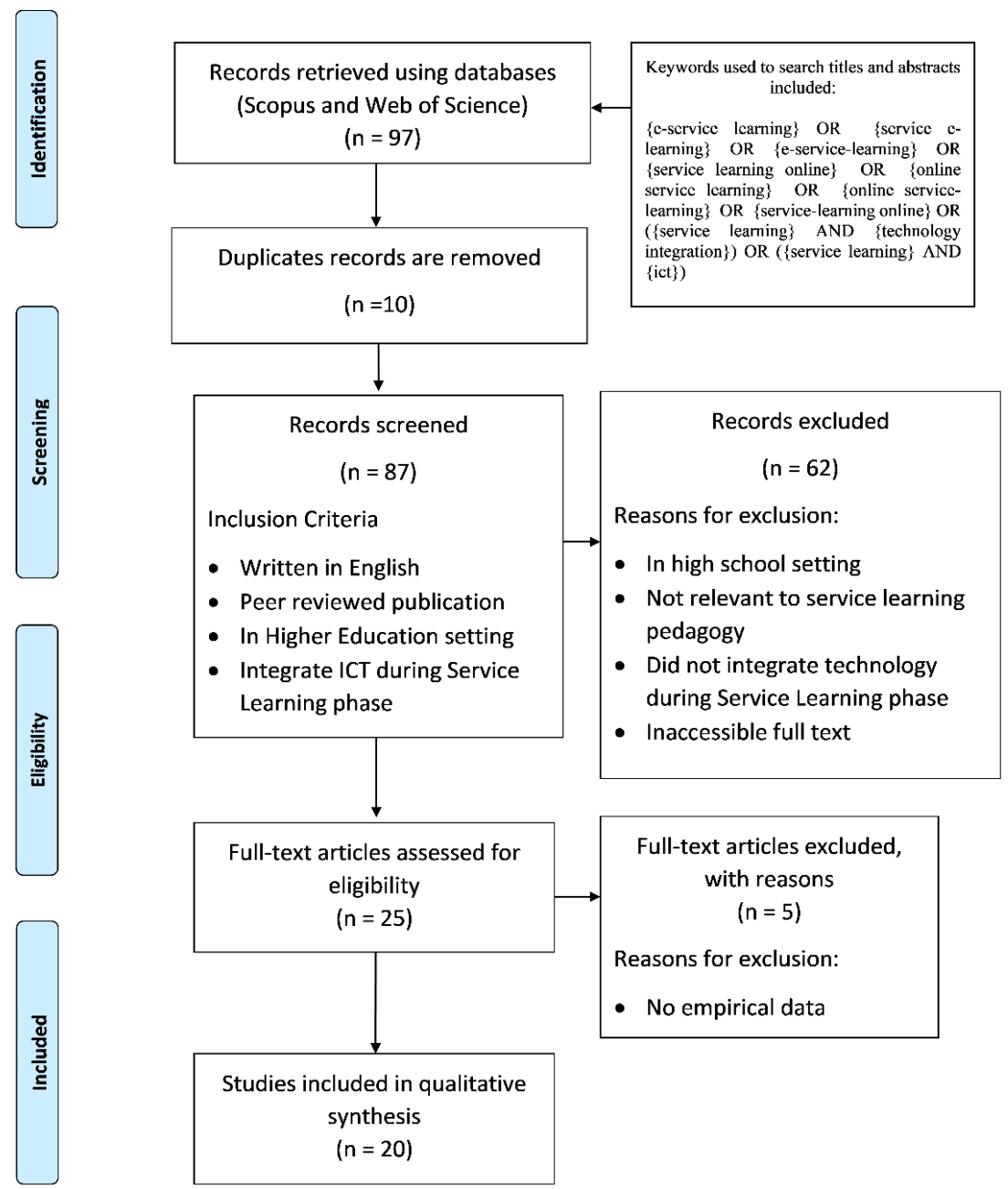

Fig. 1. A flow diagram detailing the application of PRISMA to the qualitative synthesis of published studies into e-Service Learning in Higher Education

\section{$3 \quad$ Results}

Ninety-seven published studies were identified as part of the systematic search with a final set of 20 studies included for qualitative synthesis. The review resulted in eight main areas in research regarding e-Service Learning in Higher Education setting. There are students' outcomes, challenges, success factors, impact, design and development, students' perception, reflection and comparison. The results provided a comprehensive analysis on the research area that has been studied in e-Service Learning. 
Table 3. Results according to themes

\begin{tabular}{|c|c|c|c|c|c|c|c|c|}
\hline Author & $\begin{array}{l}\text { Students' } \\
\text { Outcomes }\end{array}$ & Challenges & $\begin{array}{l}\text { Success } \\
\text { Factors }\end{array}$ & Impact & $\begin{array}{c}\text { Design } \\
\& \\
\text { Develop- } \\
\text { ment } \\
\end{array}$ & $\begin{array}{l}\text { Students' } \\
\text { Perception }\end{array}$ & Reflection & $\begin{array}{c}\text { Compari- } \\
\text { son }\end{array}$ \\
\hline Purcell [2] & & & & & I & & & \\
\hline Lawler [3] & & & 1 & & & & & \\
\hline \begin{tabular}{|l|} 
Garca- \\
Gutierrez \\
et al. [4] \\
\end{tabular} & & & & & I & & & \\
\hline Yusof [5] & 1 & & & & & & 1 & \\
\hline Griffin [6] & & & & & 1 & & & \\
\hline \begin{tabular}{|l|} 
Nielsen \\
{$[7]$}
\end{tabular} & & I & & & & & & \\
\hline Shah [8] & & & & & 1 & & & \\
\hline \begin{tabular}{|l|} 
Howlett \\
{$[9]$}
\end{tabular} & & & & & 1 & & & \\
\hline \begin{tabular}{|l|} 
Helms \\
{$[10]$}
\end{tabular} & & & & & I & & & \\
\hline Saitta [11] & & & & & 1 & & & \\
\hline Jia [12] & & 1 & & & & & & \\
\hline \begin{tabular}{|l} 
Gasper- \\
Hulvat \\
{$[13]$} \\
\end{tabular} & & & & I & & & & \\
\hline \begin{tabular}{|l|} 
McGorry \\
{$[14]$}
\end{tabular} & & & & & & & & I \\
\hline \begin{tabular}{|l} 
Marcus \\
{$[15]$}
\end{tabular} & I & & & & & & I & \\
\hline \begin{tabular}{|l|} 
Guthrie \\
and \\
McCracke \\
$\mathrm{n}[16]$ \\
\end{tabular} & & & & & & & I & \\
\hline \begin{tabular}{|l|} 
Guthrie \\
and \\
McCracke \\
n [17] \\
\end{tabular} & & & & & & I & & \\
\hline \begin{tabular}{|l} 
Salam \\
{$[18]$}
\end{tabular} & & & & & I & & & \\
\hline Chen [19] & & & & & 1 & & & \\
\hline \begin{tabular}{|l|} 
Fry [20] \\
\end{tabular} & & & & & 1 & & & \\
\hline Ruso [21] & & & & & 1 & & & \\
\hline \begin{tabular}{|l} 
Harris \\
{$[22]$}
\end{tabular} & & & & I & & & & \\
\hline
\end{tabular}

Majority of studies reviewed focused on design and development of e-Service Learning and there are eleven of them [19][20][4][6][10][9][2][21][11][18][8]. A total of two studies focused on investigating students' outcomes from the e-Service Learning environment [15][5]. These two studies mainly investigate students' generic skills with the integration of e-Service Learning platform. Two studies discussed challenges in implementing e-Service Learning [12][7], meanwhile another two studies discussed the impact of implementing online service learning [13][22]. Apart from that, there 
are also three studies that explores students' perception towards e-Service Learning [17][15][5]. A study about students' critical reflection [16], a comparison between online and traditional service learning [14] and success factors of e-Service Learning [3] resulted in one each.

Table 4. Results according to Methodology or Research Design

\begin{tabular}{|l|l|}
\hline \multicolumn{1}{|c|}{ Author } & \multicolumn{1}{c|}{ Methodology/ Research Design } \\
\hline Purcell [2] & - \\
\hline Lawler [3] & Case Study \\
\hline Garca-Gutierrez et al. [4] & - \\
\hline Yusof [5] & Mixed Methods \\
\hline Griffin [6] & - \\
\hline Nielsen [7] & - \\
\hline Shah [8] & Case Study \\
\hline Howlett [9] & Mixed Methods \\
\hline Helms [10] & \\
\hline Saitta [11] & Case Study \\
\hline Jia [12] & Case Study \\
\hline Gasper-Hulvat [13] & - \\
\hline McGorry [14] & - \\
\hline Marcus [15] & Action research \\
\hline Guthrie and McCracken [16] & - \\
\hline Guthrie and McCracken [17] & Qualitative Method \\
\hline Salam [18] & - \\
\hline Chen [19] & - \\
\hline Fry [20] & - \\
\hline Ruso [21] & Mixed Methods \\
\hline Harris [22] & - \\
\hline
\end{tabular}

In term of methodology and research design stated, majority of the research paper implement case study followed by mixed methods, action research and qualitative method.

\section{Discussion}

Since e-Service Learning is quite new to educators, a lot of researcher focusing on proposing design and development for e-Service Learning. Transitioning from traditional face-to-face Service Learning to online platform can be quite troublesome and fear a lot of educators as they see online learning as a barrier [1]. Despite learners' interest in e-Service Learning, there is too few examples of community engaged learning in fully online courses have been documented, hence resulting this trend of research area in e-Service Learning.

M. Salam et al. [18] even proposed a technological framework for e-Service Learning and they suggest that educators should integrate suitable technologies in all phases of Service Learning depending on the nature and objectives of their projects. This is important reminder to educators since different project of Service Learning requires 
different needs, and not "one size fits all". Researcher hopes that the design and development of e-Service Learning that they proposed will be able to help educators in making decision and plan what is the best implementation of e-Service Learning for their projects. Most importantly, Lawler et al. [3] highlighted that critical success factors to ensure successful implementation of digital technology service learning project are project management, strategy and technology and collaboration with organization. It is no doubt that E-Service Learning challenges educators to make full use of technology instead of replacing instructors with technology, focusing on design technology that conforms itself to the students' need, allowing the redesign and expansion of learning activities and creation of new learning possibilities that were not available previously in traditional face-to-face Service Learning setting. Flexibility also played a key role for instructors and for students [6]. Instructors that interested to integrate technology in their Service Learning project had to be flexible, think creatively and work through unexpected situations. In fact, these moments of technological failure are opportunities to model resourcefulness and creative thinking for students.

While there is an abundance of literature on service learning benefits to student's personal outcomes, the area of studies regarding students' learning outcomes in eService Learning is under-researched. In reality, e-Service Learning with technology rich environment is able to influence students' learning outcomes especially their generic skills. This is proven in study by Yusof et al. [5] and Marcus et al. [15] as they found out students also gained generic skills such as online collaborative skills, teamwork, global citizen, scholarship and adaptability with the integration of eService Learning platform. Thus, proved that hybrid strategy of service learning that combine both face-to face and online delivery can promote students' generic skills. Nielsen [7] also reported that students in online technical communication classrooms develop professional skills, contribute to the classroom and community and take greater responsibility for their education through service learning activities. Overall, the use of technologies actually enhances students' experiential learning process.

Although it is reported that service learning with technology integration had many benefits, Jia et al. [12] explores few challenges that happened among preservice teachers such as limited communication with classroom teachers, conflict between classroom teacher expectations and project requirements, inadequate project orientation and instructor support. Either way, Service Learning can create an authentic learning experience among students that connect technology integration with teaching content provided that instructors support students with project orientation and valuable feedback. Meanwhile, Nielsen [7] addresses three specific concerns that instructors in technical communication online service learning classroom encounter which are locating service opportunities, serving in isolated areas and enrolling and engaging non-traditional or part time students specifically when students need to find their own service placements. Nearly all the constraints discussed can be addressed with course planning and clear communication between all organization that involved. Course planning and communication are the most vital components in conducting online service learning classes. 
Despite study by McGorry [14] demonstrate that there is no significant difference in outcomes between the online and face-to-face models, implementing Service Learning online is able to cater to the needs of digital natives learners nowadays. Both setting produced similar outcomes but transitioning to online service learning will not just improve students' personal development but also affecting their media literacy skills. As we are moving into era of globalization, future graduates are expected to access, analyze, evaluate, create, and act using all forms of communication. Media literacy is an essential skill in this digital skills and instructors should not be afraid of trying new methodologies suits with their own service-learning projects. As Internet technologies have become part of the daily communication pattern of a new generation of students, who see it as their natural environment in which to learn, play and work, thus it is important to expand students' use of the global digital network from superficial social interactions towards activities which enable them to become active and informed global citizens [22].

Instructors that often concern with disengage student in their online service learning course may consider using reflection journals to help students to connect their service to learning in the coursework as suggested by Guthrie and McCracken [16].

They found out that students felt reflection was essential to learning in order to gain multiple perspectives and being introduced to a diversity of ideas. Most importantly, students were empowered to assess their own individual learning goals and collaborate with others to make meaning of their service learning experience. Reflection process is so much easier and richer with the use of technology in e-Service Learning platform. Students that involved in e-Service Learning also reported a strong sense of learning from the open discussion. According to Guthrie and McCracken [17], active discussions and intentionally structured assignments support personal reflection and collaborative learning when implement within technology-rich learning environments.

Apart from this, majority of the studies reviewed employed a case study method as they attempted to explore a unique and new phenomenon in educational area such as e-Service Learning. Most of the case study is an exploratory process and make use of interviews and self-reflecting documents such as reflection to gain insight regarding e-Service Learning. Garca-Gutierrez et al. [4] noted that the best way to access this learning experience would be a narrative method - that is, the students themselves would tell us, through a semi-structured report, about their own experiences. In this way, the students collected the information and their experience in a descriptive and reflective way in their field notes.

\section{Conclusion}

The findings of this systematic review suggest that research regarding design and development of e-Service Learning is the most highly researched due to the transition of traditional Service Learning to online Service Learning to cater the need of digital learners nowadays, and also to guide instructors that is interested to implement technology in their Service Learning course. This review has several limitations. Firstly, 
our review was limited to two journal databases due to authors would like articles came from peer-reviewed journals. It is believed that related studies in e-Service Learning has been published in non-indexed journals and may be included in future research to provide extensive overview of research area that has been discovered. Our review was quite extensive, but some articles need to be excluded as authors have no access to it. Although there are few researches investigate the effect of e-Service Learning on students' personal development, we believe that there is a need to dig deeper in researching about what happened among students during service learning especially when we are integrating technology. Any learning process involving technology and ICT often related with the lack of connection among learners and learning materials. Therefore, it is important for future research looking into students' engagement with learning process and analyzing their social network among each other. For future studies, more guidance should be used in the project to help students reflect on their technology integration-related beliefs, knowledge, and skills.

\section{References}

[1] L. S. Waldner, M. C. Widener, and S. Y. McGorry, "E-service learning: The evolution of service-learning to engage a growing online student population," J. High. Educ. Outreach Engagem., vol. 16, no. 2, pp. 123-150, 2012.

[2] J. W. Purcell, "Community-Engaged Pedagogy in the Virtual Classroom: Integrating eService-Learning Into Online Leadership Education,” J. Leadersh. Stud., vol. 11, no. 1, pp. 65-70, 2017. https://doi.org/10.1002/jls.21515

[3] J. Lawler, "Critical success factors for partnering with nonprofit organizations on digital technology service-learning projects: A case study," in Higher education, emerging technologies, and community partnerships: Concepts, models and practices, IGI Global, 2011, pp. 106-123. https://doi.org/10.4018/978-1-60960-623-7.ch010

[4] J. Garca-Gutierrez, M. Ruiz-Corbella, and A. del Pozo Armentia, "Developing Civic Engagement in Distance Higher Education: A Case Study of Virtual Service-Learning (vSL) Programme in Spain," Open Prax., vol. 9, no. 2, pp. 235-244, 2017. https://doi.org/10.59 44/openpraxis.9.2.578

[5] A. Yusof, N. A. Atan, J. Harun, and M. Doulatabadi, "Developing students graduate attributes in service learning project through online platform," 2019.

[6] M. Griffin, E. Saitta, M. Bowdon, and L. J. Walters, "Engaging stem: Service-learning, technology, science education and community partnerships," in Higher Education, Emerging Technologies, and Community Partnerships: Concepts, Models and Practices, IGI Global, 2011, pp. 51-56. https://doi.org/10.4018/978-1-60960-623-7.ch005

[7] D. Nielsen, "Facilitating service learning in the online technical communication classroom," J. Tech. Writ. Commun., vol. 46, no. 2, pp. 236-256, 2016.

[8] R. W. Shah, J. M. Troester, R. Brooke, L. Gatti, S. Thomas, and J. E. Masterson, "Fostering eABCD: Asset-Based Community Development in Digital Service-Learning," J. High. Educ. Outreach Engagem., vol. 22, no. 2, pp. 189-222, 2018.

[9] K. M. Howlett, J. Allred, D. Beck, and A. R. Mysore, "An english learner service-learning project: Preparing education majors using technology and the SAMR model.," CALL-EJ, vol. 20, no. 2, pp. 128-149, 2019. 
[10] M. M. Helms, R. M. Rutti, A. A. Hervani, J. LaBonte, and S. Sarkarat, "Implementing and evaluating online service learning projects," J. Educ. Bus., vol. 90, no. 7, pp. 369-378, 2015. https://doi.org/10.1080/08832323.2015.1074150

[11] E. K. H. Saitta, M. A. Bowdon, and C. L. Geiger, "Incorporating service-learning, technology, and research supportive teaching techniques into the university chemistry classroom," J. Sci. Educ. Technol., vol. 20, no. 6, pp. 790-795, 2011. https://doi.org/10.1007/s10956010-9273-0

[12] X. Jia, J. Jung, and A. Ottenbreit-Leftwich, "Learning technology integration from a service-learning project: Connecting preservice teachers to real-world problems," J. Exp. Educ., vol. 41, no. 3, pp. 261-276, 2018. https://doi.org/10.1177/1053825917738269

[13] M. Gasper-Hulvat, "“More Like a Real Human Being': Humanizing Historical Artists Through Remote Service-Learning,” J. Exp. Educ., vol. 41, no. 4, pp. 397-410, 2018. https ://doi.org/10.1177/1053825918808321

[14] S. Y. McGorry, "No significant difference in service learning online.," J. Asynchronous Learn. Networks, vol. 16, no. 4, pp. 45-54, 2012.

[15] V. B. Marcus, N. A. Atan, R. Talib, A. A. Latif, and S. M. Yusof, "Promoting Students' Generic Skills with the Integration of e-Service Learning Platform,” Int. J. Emerg. Technol. Learn., vol. 14, no. 20, pp. 4-17, 2019. https://doi.org/10.3991/ijet.v14i20.11455

[16] K. L. Guthrie and H. McCracken, "Reflection: the importance of making meaning in eservice-learning courses," J. Comput. High. Educ., vol. 26, no. 3, pp. 238-252, 2014. https ://doi.org/10.1007/s12528-014-9087-9

[17] K. L. Guthrie and H. McCracken, "Teaching and learning social justice through online service-learning courses,” Int. Rev. Res. Open Distrib. Learn., vol. 11, no. 3, pp. 78-94, 2010. https://doi.org/10.19173/irrodl.v11i3.894

[18] M. Salam, D. N. A. Iskandar, D. H. A. Ibrahim, and M. S. Farooq, "Technology integration in service-learning pedagogy: A holistic framework," Telemat. Informatics, vol. 38, pp. 257-273, 2019. https://doi.org/10.1016/j.tele.2019.02.002

[19] C.-H. Chen, C.-H. Liao, Y.-C. Chen, and C.-F. Lee, "The integration of synchronous communication technology into service learning for pre-service teachers' online tutoring of middle school students," Internet High. Educ., vol. 14, no. 1, pp. 27-33, 2011. https://doi. org/10.1016/j.iheduc.2010.02.003

[20] G. W. Fry, "The Interface between Experiential Learning and the Internet: ways for improving learning productivity," Horiz., vol. 10, no. 3, pp. 5-11, 2002.

[21] N. Ruso, "The Role of Technology: Community Based Service-Learning Projects on Ethical Development.," Turkish Online J. Educ. Technol., vol. 11, no. 3, pp. 375-385, 2012.

[22] U. S. Harris, "Virtual partnerships: Engaging students in e-service learning using computer-mediated communication," Asia Pacific Media Educ., vol. 27, no. 1, pp. 103-117, 2017. https://doi.org/10.1177/1326365x17701792

\section{$7 \quad$ Authors}

Valerie Bukas Marcus is affiliated with the School of Education, Faculty of Social Sciences and Humanities, Universiti Teknologi Malaysia, 81310 Skudai, Johor Bahru, Johor, Malaysia. Valerie Bukas Marcus area of interest is eLearning. For more details contact at, valeriebukas92@gmail.com 
Noor Azean Atan Is currently affiliated with the School of Education, Faculty of Social Sciences and Humanities, Universiti Teknologi Malaysia, 81310 Skudai, Johor Bahru, Johor, Malaysia. Author area of interest is eLearning and online learning.

Sanitah Mohd Yusof Is currently affiliated with School of Education, Faculty of Social Sciences and Humanities, Universiti Teknologi Malaysia, 81310 Skudai, Johor Bahru, Johor, Malaysia. Author area of area of interest is eLearning.

Lokman Tahir Is affiliated with School of Education, Faculty of Social Sciences and Humanities, Universiti Teknologi Malaysia, 81310 Skudai, Johor Bahru, Johor, Malaysia. Author area of interest is eLearning and online learning.

Article submitted 2020-01-24. Resubmitted 2020-02-22. Final acceptance 2020-02-22. Final version published as submitted by the authors. 